\title{
Stimulation of aerobic degradation of bentazone, mecoprop and dichlorprop by oxygen addition to aquifer sediment
}

Levi, Suzi; Hybel, Anne-Marie; Bjerg, Poul Løgstrup; Albrechtsen, Hans-Jørgen

Published in:

Science of the Total Environment

Link to article, DOI:

10.1016/j.scitotenv.2013.12.061

Publication date:

2014

Document Version

Peer reviewed version

Link back to DTU Orbit

Citation (APA):

Levi, S., Hybel, A-M., Bjerg, P. L., \& Albrechtsen, H-J. (2014). Stimulation of aerobic degradation of bentazone, mecoprop and dichlorprop by oxygen addition to aquifer sediment. Science of the Total Environment, 473-474, 667-675. https://doi.org/10.1016/j.scitotenv.2013.12.061

\section{General rights}

Copyright and moral rights for the publications made accessible in the public portal are retained by the authors and/or other copyright owners and it is a condition of accessing publications that users recognise and abide by the legal requirements associated with these rights.

- Users may download and print one copy of any publication from the public portal for the purpose of private study or research.

- You may not further distribute the material or use it for any profit-making activity or commercial gain

- You may freely distribute the URL identifying the publication in the public portal 
This is a post-print of a published manuscript in The Science of the Total Environment The publisher's version can be found 10.1016/j.scitotenv.2013.12.061

\title{
STIMULATION OF AEROBIC DEGRADATION OF BENTAZONE, MECOPROP AND DICHLORPROP BY OXYGEN ADDITION TO AQUIFER SEDIMENT
}

\author{
Levi, S. ${ }^{1}$, Hybel, A.-M. ${ }^{1}$, Bjerg, P. L. ${ }^{1}$, Albrechtsen, H.-J. ${ }^{1 *}$ \\ ${ }^{1}$ Technical University of Denmark, DTU Environment, Department of Environmental \\ Engineering, Miljoevej 113, 2800 Kongens Lyngby, Denmark
}

Corresponding author

Telephone: (+45) 45251586

Fax: (+45) 45932850

Email: hana@env.dtu.dk 


\section{Abstract}

In order to investigate aerobic degradation potential for the herbicides bentazone, mecoprop and dichlorprop, anaerobic groundwater samples from two monitoring and three drinking water wells near a drinking water abstraction field in Nybølle, Denmark, were screened for their degradation potential for the herbicides. In the presence of oxygen ${ }^{14}$ C-labelled bentazone and mecoprop were removed significantly from the two monitoring wells’ groundwater samples. Oxygen was added to microcosms in order to investigate whether different oxygen concentrations stimulate the biodegradation of the three herbicides in microcosms using groundwater and sandy aquifer materials. To maintain a certain oxygen concentration this level was measured from the outside of the bottles with a fiber oxygen meter using oxygen-sensitive luminescent sensor foil mounted inside the microcosm, to which supplementary oxygen was added. The highest oxygen concentrations (corresponding to $4-11 \mathrm{mg} \mathrm{L}^{-1}$ ) stimulated degradation (a 14-27\% increase for mecoprop, 3-9\% for dichlorprop and 15-20\% for bentazone) over an experimental period of 200 days. Oxygen was required to biodegrade the herbicides, since no degradation was observed under anaerobic conditions. This is the first time bentazone degradation has been observed in aquifer material at low oxygen concentrations $\left(2 \mathrm{mg} \mathrm{L}^{-1}\right)$. The sediment had substantial oxygen consumption (0.92$1.45 \mathrm{mg} \mathrm{O}_{2} \mathrm{~g}^{-1} \mathrm{dw}$ over 200 days) and oxygen was depleted rapidly in most incubations soon after its addition, which might be due to the oxidation of organic matter and other reduced species such as $\mathrm{Fe}^{2+}, \mathrm{S}^{2-}$ and $\mathrm{Mn}$ in sediment before the biodegradation of herbicides takes place. This study suggests that oxygen enhancement around a drinking water abstraction field could stimulate the bioremediation of diffuse source contamination. 
Keywords: herbicides mecoprop, dichlorprop and bentazone; groundwater; anaerobic aquifer; oxygen addition; enhanced aerobic degradation

\section{Introduction}

Herbicides, such as 3-Isopropyl-1H-2,1,3-benzothiadiazin-4(3H)-one-2,2dioxide (bentazone) and phenoxy acids (PA) 4-chloro-2-methylphenoxypropanoicacid (mecoprop) and 2,4-dichlorophenoxypropanoicacid (dichlorprop) are used extensively in agriculture as well as in public areas and gardens. Due to their relatively high solubility in water (Huber and Otto, 1994; Tomlin, 1997) and low sorption characteristics, they leach from the soil into aquifers and are often detected in groundwater (Barbash et al., 2001; Thorling et al., 2012; Malaguerra et al., 2012). Consequently, they pose a threat to drinking water supplies based on groundwater sources. Groundwater contamination with herbicides from diffuse sources is widespread, but it is usually at low concentrations in the nano- to microgram per litre concentration range (Kolpin et al., 1995; 2000; Thorling et al., 2012). This limits the possibilities for remedial actions in contrast to contamination from a point source characterized by higher concentrations, smaller volumes and distinct plumes (Tuxen et al., 2006a).

The degradation of pesticides in aquifers depends on the physicochemical properties and degradability of the pesticides as well as the redox conditions present at the site. For instance, bentazone is biodegradable in topsoils under aerobic conditions (Huber and Otto, 1994; Leistra et al., 2001; Li et al., 2008; Rodriguez-Cruz et al., 2008; Larsbo et al., 2009), but it appears to be recalcitrant in aquifers under aerobic conditions 
(Tuxen et al., 2000; Broholm et al., 2001). In contrast, the degradation of mecoprop and dichlorprop has been observed both in topsoil (Smith, 1989) and in aquifers under aerobic conditions (see the reviews of Buss et al., 2006; Reitzel et al., 2004; Janniche et al., 2010).

Redox conditions are very important for the degradation of herbicides in groundwater. One approach for enhancing biodegradation in soil is the addition of electron acceptors, such as oxygen or nitrate, in order to stimulate indigenous microbial populations (Kanissery and Sims, 2011). Adding oxygen can enhance the aerobic biodegradation of phenoxy acids at high concentrations (45 $\left.\mu \mathrm{g} \mathrm{L}^{-1}\right)$ in anaerobic aquifer materials emanating from phenoxy acid-contaminated point sources (Tuxen et al., 2006b). We built upon the work of Tuxen et al. (2006a) and investigated the potential aerobic degradation of herbicides in aquifer materials at low concentrations $\left(1 \mu \mathrm{L} \mathrm{L}^{-1}\right)$ near to an operating drinking water abstraction field. Our experiments investigated whether enhanced oxygen concentrations around an abstraction well field could be a treatment option. The goal was to stimulate the degradation of a persistent herbicide bentazone - as well as the phenoxy acids mecoprop and dichlorprop in groundwater and aquifer sediment.

Bringing degradation potential observed in a laboratory out into the field is challenging. First, increasing the oxygen content in an aquifer may be difficult from a hydraulic and engineering point of view. However, providing sufficient amounts of oxygen with "smart” pumping strategies in or around drinking water abstraction wells may be possible. Second, oxygen-consuming processes related to organic matter and 
reduced inorganic species present in the sediment, such as sulphide and ferrous iron, may be obstacles for point source application with complex geochemistry (Tuxen et al., 2006a). This may in turn reduce oxygen concentrations below levels sufficient to support pesticide degradation. However, little is known of the oxygen concentrations required for aerobically degrading herbicides. Furthermore, oxygen demand is expected to be lower in pristine or diffuse source contaminated aquifers than in near point sources due to fewer reduced species (Heron and Christensen, 1995; Christensen et al., 2000; Hartog et al., 2002). Oxygen consumption by groundwater and the total amount of oxygen needed to obtain oxic conditions could be estimated based on the demand for oxygen by other dissolved compounds (Heron and Christensen, 1995), but determining the oxygen demand of the solid phase requires experiments with actual aquifer materials from the site.

The aim of this study was to investigate (1) whether adding oxygen to anaerobic aquifer material would stimulate the biodegradation of bentazone, mecoprop and dichlorprop in laboratory microcosm experiments, (2) how much oxygen would be needed in order to significantly affect the biodegradation process and (3) how much oxygen would be consumed by the sediment compared to the amount of oxygen needed for pesticide degradation. The three herbicides were selected in order to relate the experiments to the recent detection of bentazone and dichlorprop at the Nybølle drinking water abstraction well field, to facilitate a comparison with previous experimental work with mecoprop (Tuxen et al., 2006b) and to improve knowledge of degradation in bentazone, a herbicide detected frequently worldwide and in Denmark. 


\section{Materials and Methods}

\subsection{Nybølle site description}

Groundwater and sediment samples were obtained from a drinking water abstraction well field located in the town of Nybølle in the northern part of Zealand, Denmark (Figure 1). The upper aquifer is composed of sand, gravel and clay layers (Quaternary layers) underlain by a 10-30m thick chalk layer (Bryozoa). The water table is located $3 \pm 1 \mathrm{~m}$ below the ground surface (mbs). The chalk aquifer in Nybølle is protected only by thin clay till layer (approximately 5m deep). Different herbicides, including bentazone and dichlorprop, have been detected in concentrations up to 0.25 $\mu \mathrm{g} \mathrm{L}^{-1}$ in the groundwater around the town (Rambøll, 2005). Site history, hydrogeology and groundwater quality have been described in detail elsewhere (Jessen, 2001; Region Hovedstaden, 2008).
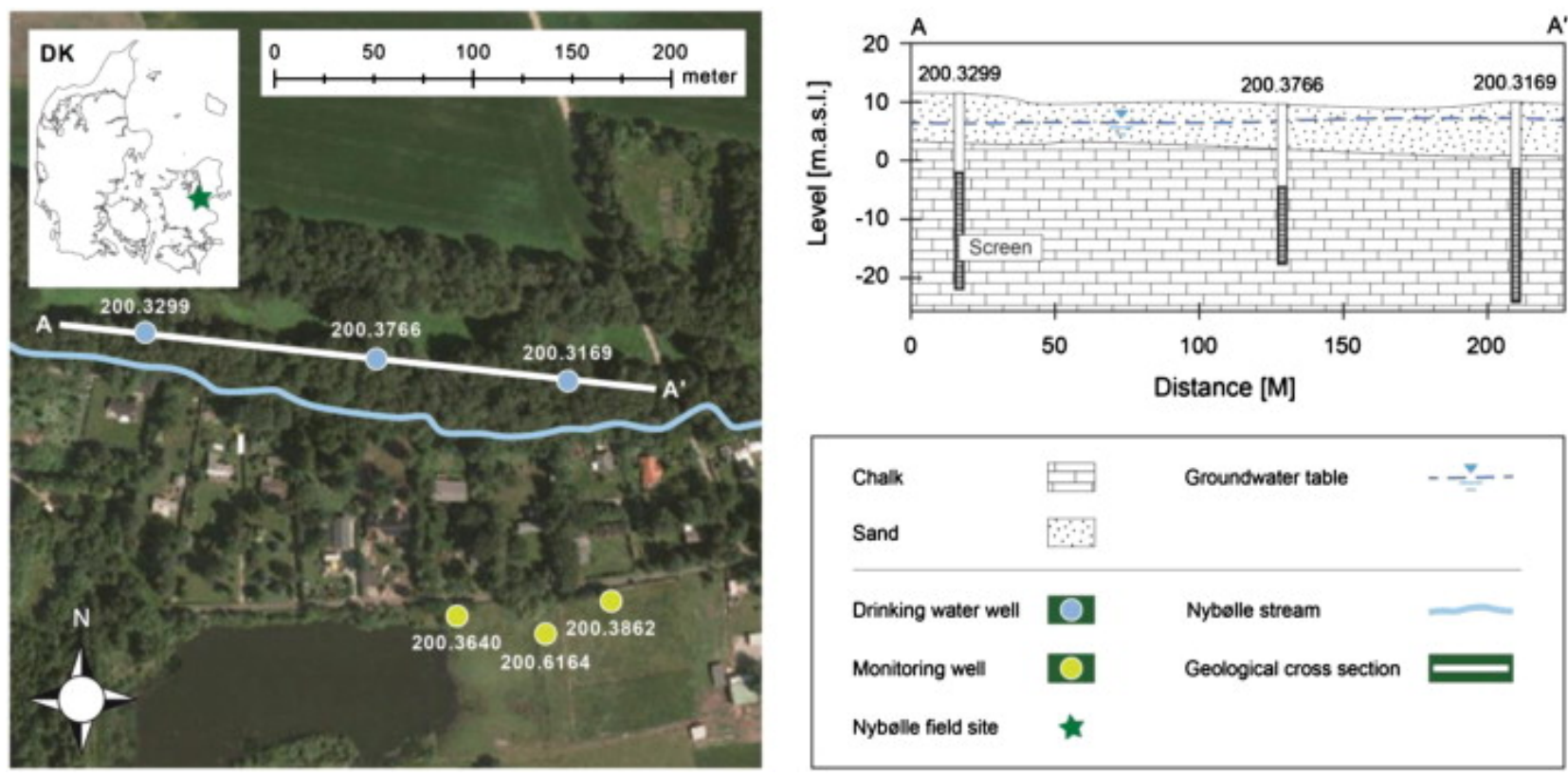

Fig. 1. The Nybølle abstraction field site, locations of the investigated wells and a geological profile of drinking water abstraction wells in Nybølle along the cross Section A-A'. The sediment samples were collected next to monitoring Well 200.2164. 


\subsection{Groundwater sampling}

Groundwater at the Nybølle site, which was sampled in February 2010 from monitoring wells I (DGU-nr. 200.3640) and II (DGU-nr. 200.3862) as well as drinking water abstraction wells III (DGU-nr. 200.3299), IV (DGU-nr. 200.3169) and V (DGUnr. 200.3766) (Figure 1) (Table 2), abstracted using an MP1 pump (Ø: 50 mm) lowered to $1 \mathrm{~m}$ above the screen after at least three volumes of well water had been discarded. The water was collected in 1L glass bottles, filled by creating an overflow, and capped tightly in order to prevent oxygen contamination. The sampling of groundwater from monitoring well II (DGU-nr.200.3862) was repeated in December 2010. In addition, water samples were collected in 1L glass bottles from three screens (B1, B2 and B3) in monitoring well DGU-nr. 200.6164, in order to determine pesticide concentrations at different depths of the aquifer.

\begin{tabular}{l} 
Table 1 \\
Physical structures and chemical properties for the herbicides included in this study (physio-chemical data from Tomlin, 1997). \\
\hline Chemical name
\end{tabular}




\subsection{Sediment sampling}

Sediment cores (2.3 to $7.1 \mathrm{mbs}$ ) were collected in December 2010 less than $1 \mathrm{~m}$ from monitoring well DGU-nr.200.6164 (2.3 to $7.1 \mathrm{mbs})$ using a Geoprobe ${ }^{\circledR}$ macro corer (Figure 1). The collected sediment cores (PVC lines, Ø: $50 \mathrm{~mm}$ ) were flushed in the field immediately with nitrogen gas to prevent oxygen contamination, sealed at both ends with plastic stoppers and wrapped in aluminum foil.

\begin{tabular}{|c|c|c|c|c|c|c|c|c|c|}
\hline \multirow[t]{2}{*}{ Parameter } & & \multirow[t]{2}{*}{200.3640 Well I } & \multirow[t]{2}{*}{200.3862 Well II } & \multirow[t]{2}{*}{ 200.3299 Well III } & \multirow[t]{2}{*}{ 200.3169 Well IV } & \multirow[t]{2}{*}{ 200.3766 Well V } & \multicolumn{3}{|c|}{200.6164} \\
\hline & & & & & & & B1 & B2 & B3 \\
\hline Purpose & & Monitoring & Monitoring & Drinking water & Drinking water & Drinking water & \multicolumn{3}{|c|}{$\begin{array}{l}\text { Wells for experimental } \\
\text { set up }\end{array}$} \\
\hline Geological strata & & Chalk & Chalk & Chalk & Chalk & Chalk & Sand & Sand & Sand \\
\hline \multicolumn{10}{|l|}{ Pesticides } \\
\hline Mecoprop & $\mu \mathrm{g} \mathrm{L}^{-1}$ & b.d. & b.d. & b.d. & b.d. & b.d. & b.d. & b.d. & b.d. \\
\hline Dichlorprop & $\mu \mathrm{g} \mathrm{L}^{-1}$ & 0.059 & 0.051 & b.d. & b.d. & b.d. & 0.11 & b.d. & b.d. \\
\hline Bentazone & $\mu \mathrm{g} \mathrm{L}^{-1}$ & 0.071 & b.d. & b.d. & b.d. & 0.018 & b.d. & b.d. & b.d. \\
\hline 4-СРP & $\mu \mathrm{g} \mathrm{L}^{-1}$ & - & 0.16 & b.d. & b.d. & b.d. & 0.56 & b.d. & b.d. \\
\hline BAM & $\mu \mathrm{g} \mathrm{L}^{-1}$ & b.d. & 0.091 & b.d. & b.d. & b.d. & 0.75 & b.d. & b.d. \\
\hline \multicolumn{10}{|l|}{ Chlorophenols } \\
\hline 2,4-dichlorphenol & $\mu \mathrm{g} \mathrm{L}^{-1}$ & b.d. & b.d. & b.d. & b.d. & b.d. & b.d. & b.d. & b.d. \\
\hline 2,6-dichlorphenol & $\mu \mathrm{g} \mathrm{L}^{-1}$ & b.d. & b.d. & b.d. & b.d. & b.d. & b.d. & b.d. & b.d. \\
\hline 4-chlor-2-methylphenol & $\mu \mathrm{g} \mathrm{L}^{-1}$ & b.d. & b.d. & b.d. & b.d. & b.d. & b.d. & b.d. & b.d. \\
\hline
\end{tabular}

Note: b.d., below detection limit. The detection limit was $0.01 \mu \mathrm{g} \mathrm{\textrm {L } ^ { - 1 }}$.

In addition, a chalk core was provided by NIRAS from well K2, Hellestedvej 22, Hellested, at a depth of 14.65-14.95 mbs (Damgaard et al., 2009). The collected sediment cores and groundwater samples from the Nybølle site were kept at $10^{\circ} \mathrm{C}$ until the experiments were set up, no later than five days after collection.

\subsection{Groundwater and sediment characterisation}

The oxygen, $\mathrm{pH}$, temperature and electrical conductivity levels of the collected groundwater samples were measured in the field with a flow cell (WTW Microprocessor pH meter and a WTW microprocessor oximeter). The groundwater samples were filtered through $0.2 \mu \mathrm{m}$ and $0.45 \mu \mathrm{m}$ membrane filters, except the samples used for analysing methane and microbial activity (ATP) measurements. The 
groundwater samples were preserved by adding four drops of 4M HNO3 $(\mathrm{pH}<2)$ on site so that they could be analysed in the laboratory for chloride, nitrate, sulphate, ferrous iron, ammonium, dissolved manganese and magnesium, calcium, potassium and dissolved organic carbon (DOC) (Milosevic et al., 2012). Pesticide analyses were conducted by Eurofins Miljoe A/S Laboratories, Denmark. The detection limit was 0.01 $\mu \mathrm{g} \mathrm{L}^{-1}$ for all pesticide compounds in the water samples.

The water content of the mixed sediment samples from 2.3-7.1 mbs was measured for weight loss after $24 \mathrm{~h}$ at $105^{\circ} \mathrm{C}$. Total organic carbon (TOC) of the solids was measured with a total elemental analyser (LECO CS-225) after removing the inorganic carbon (TIC) by adding $6 \% \mathrm{H}_{2} \mathrm{SO}_{3}$. Grain size distribution was characterized by sieving (sieves $0.063-2.0 \mathrm{~mm}$ ) and for particles below $63 \mu \mathrm{m}$ by particle distribution (Sedigraph 5100, Micromeritics Gemini). The specific surface area was measured by utilising multipoint $\mathrm{N}_{2}$-BET analysis (Micromeritics, Gemini III 2375 surface area analyser), after outgassing (Micromeritics, FlowPrep 060 Degasser) for $4 \mathrm{~h}$ at $70^{\circ} \mathrm{C}$, as described by Janniche et al. (2011). Grain volume ( $\mathrm{V}_{\mathrm{g}}$ ) was measured with a Helium porosimeter (Edinburg Petroleum Service HGP 100, England), while porosity was calculated from Vg and total volume $\left(\mathrm{V}_{\mathrm{t}}\right)$.

\subsection{Herbicides}

The experiments were carried out with [carbonyl-14C] Bentazone (Izotop, Budapest, Hungary, 97.96\% radiochemical purity, $44 \mathrm{mCi} \mathrm{mmol}^{-1}$ ) and two phenoxy acid herbicides, [ring- ${ }^{14} \mathrm{C}$ ] mecoprop (Izotop, Budapest, Hungary, 95\% radiochemical purity, $23 \mathrm{mCi} \mathrm{mmol}{ }^{-1}$ ), [ring- ${ }^{14} \mathrm{C}$ ] dichlorprop (Izotop, Budapest, Hungary, 99.03\% radiochemical purity, $25 \mathrm{mCi} \mathrm{mmol}^{-1}$ ) (Table 1). 


\subsection{Mineralisation potential in groundwater}

In order to investigate mineralisation potential, groundwater samples from the monitoring wells and drinking water abstraction wells were incubated (seesection 2.2). . The chalk sediment from the Hellested site was crushed in a plastic bag with a sledge hammer prior to setting up the experiments. Before adding th water samples all bottles with chalk sediment were autoclaved three times at 1.5 bars and $120^{\circ} \mathrm{C}$ to ensure that active bacteria present in the bottles originated from the groundwater and not from the chalk. Autoclaved chalk sediment was added as a substratum for the bacteria. The microcosms were incubated for 200 days in the dark at $10^{\circ} \mathrm{C}$ under atmospheric airsaturated conditions. A total of 18 incubations were set up with $40 \mathrm{~g}$ autoclaved chalk and $60 \mathrm{~mL}$ groundwater added to $100 \mathrm{~mL}$ DURAN bottles with Teflon inlayer caps, as described by Janniche et al. (2011). Groundwater from two monitoring wells (Well I and II) was used for the bentazone and mecoprop investigations, while the dichlorprop experiments were set up with groundwater from the monitoring and drinking water abstraction wells (Well I, II, III, IV and V). Well I and II were chosen for bentazone experiments due to the high concentrations of bentazone detected in the wells. The wells for mecoprop and dichlorprop experiments were selected randomly. [carbonyl- ${ }^{14} \mathrm{C}$ ] labelled bentazone, [ring- ${ }^{14} \mathrm{C}$ ] labelled mecoprop and dichlorprop were added separately to the microcosms at a concentration of $1 \mu \mathrm{g} \mathrm{L}^{-1}$. Control incubations were prepared by autoclaving three times at $20 \mathrm{~min}$ at 1.5 bars and $121^{\circ} \mathrm{C}$.

For ${ }^{14} \mathrm{C}$ - activity measurements, $2 \mathrm{~mL}$ water subsamples were collected, filtered through a $0.2 \mu \mathrm{m}$ PTFEfilter (Advantec/MFS 13HP) and then transferred to a $20 \mathrm{~mL}$ polyethylene scintillation vial containing a $6 \mathrm{ml}$ scintillation vial with $1 \mathrm{~mL} 0.5 \mathrm{~m} \mathrm{NaOH}$ 
(Janniche et al., 2011). The subsamples were acidified by adding $0.1 \mathrm{~mL} 37 \% \mathrm{HCl}$ to strip off ${ }^{14} \mathrm{CO}_{2}$. The $6 \mathrm{~mL}$ inner vial of this 'double vial' system served as a $\mathrm{CO}_{2}$ trap and was removed after 48 hours. Scintillation liquid (Optiphase HiSafe 3, Wallac) was added and the ${ }^{14} \mathrm{C}$-activity of both the $20 \mathrm{~mL}$ vial and the $6 \mathrm{~mL}$ vial was quantified by counting for 20 minutes in a liquid scintillation counter (WinSpectralTM, Wallac 1414 Liquid Scintillation Counter).

2.7. Stimulated mineralisation with groundwater and sandy sediment from the Nybølle site

The effect of stimulating the degradation potential of herbicides by applying different oxygen concentrations was investigated through the use of groundwater and aquifer material collected freshly from the Nybølle site. Laboratory batch microcosms were set up with anaerobic groundwater from monitoring well II (DGU-nr.200.3862) and anaerobic aquifer sediment samples from DGU-nr. 200.6164, including the sandy layer only at a depth of 2.3-7.1 m.b.s. (Figure 1 ). The outer $0.5 \mathrm{~cm}$ of the sediment core which may have been in contact with the core barrel was removed. In total, 48 incubations were set up with $40 \mathrm{~g}$ wet aquifer material (sediment and pore water) and $3.5 \mathrm{~mL}$ groundwater in $50 \mathrm{~mL}$ sterilized infusion glass bottles with butyl rubber stoppers in an anaerobic glove box (Coy Laboratory Products, Inc.) (Tuxen et al., 2006b). ${ }^{14} \mathrm{C}$ herbicides were added separately to the microcosm, to a final concentration of $1 \mu \mathrm{g} \mathrm{L}{ }^{-1}$ of each pesticide. The bottles were then flushed with an $80 \% \mathrm{~N}_{2} / 20 \% \mathrm{CO}_{2}$ gas mixture in order to remove any trace amounts of hydrogen gas from the anaerobic box.

Pure oxygen was added to the microcosm bottles to a final concentration of 0.1 , $0.5,1,2,4,5,8,9$ or $11 \mathrm{mg} \mathrm{L}^{-1}$ at the beginning of the experiment, while two bottles 
remained anaerobic. The amount of pure oxygen to be added to each microcosm, in order to reach the desired oxygen concentrations, was calculated in the PHREEQC program (Pankhurst and Appelo, 1999). During the experiment the oxygen concentrations in the bottles were measured from outside with a fiber optical oxygen meter (PreSens precision Sensing GmbH) using oxygen-sensitive luminescent sensor foil mounted inside the microcosms. The detection limit was $0.15 \mathrm{mg} \mathrm{L}^{-1}$. If the oxygen concentration decreased, additional oxygen was added, and the bottles were shaken for 10-15 min before and after this addition. Each bottle was equipped with a glass vial with $1 \mathrm{~mL} 0.5 \mathrm{~m} \mathrm{NaOH}$ to trap the evolved ${ }^{14} \mathrm{CO}_{2}$. At regular intervals $\mathrm{NaOH}$ was collected by a syringe through the butyl stoppers, mixed with a $10 \mathrm{~mL}$ Wallac OptiPhase Hisafe 3 scintillation cocktail (Turku, Finland) and then counted by a WinSpectralTM, Wallac 1414 liquid scintillation counter to quantify pesticide mineralisation. Abiotic control incubations were prepared by autoclaving the microcosms with groundwater and sediment three times at one-day intervals for $20 \mathrm{~min}$ at 1.5 bars and $121^{\circ} \mathrm{C}$ before pesticide addition. Duplicates were set up for bottles with oxygen concentrations of 0.1 and $11 \mathrm{mg} \mathrm{L}^{-1}$. The microcosms were incubated in the dark at $10^{\circ} \mathrm{C}$ for 200 days.

\section{Results and discussion}

\subsection{Groundwater and sediment characterisation}

The drinking water abstraction wells were screened in the chalk aquifer, which was overlaid by Quaternary layers of 10m of sand, gravel and clay till deposits (Figure 1). The primary aquifer was approximately $30 \mathrm{~m}$ thick. The monitoring wells were screened mainly in the upper Quaternary strata (see Table 2). The sediment sample used for the experimental work was characterized as sandy (57 $\pm 23 \%)$ with a silt content of 
$16 \pm 5.6 \%$ and a clay content of only $3.1 \pm 2.2 \%$. The organic carbon content (TOC) of the sediment was $0.18 \%$.

Phenoxy acids, related chlorophenols, bentazone and a few other pesticides were identified in groundwater samples at the Nybølle site (Table 2). The concentrations of dichlorprop (0.11 $\left.\mu \mathrm{g} \mathrm{L}^{-1}\right)$, 4-CPP (0.56 $\left.\mu \mathrm{g} \mathrm{L}^{-1}\right)$ and 2,6-diclorbenzamid (BAM) (0.75 $\mu \mathrm{g}$ $\mathrm{L}^{-1}$ ) were highest in the samples taken from monitoring well DGU-nr. 200.6164 (screen B1). 4-CPP may either be an impurity from the production of phenoxy acids or a metabolite (Reitzel et al. 2004; Milosevic et al., 2013). Mecoprop and chlorophenols, such as 2,4-dichlorphenol, 2,6-dichlorphenol and 4-chlor-2-methylphenol, were not detected in any of the groundwater samples. Bentazone was detected in groundwater samples from well I (200.3640) (0.071 $\left.\mu \mathrm{g} \mathrm{L}^{-1}\right)$ and well V (200.3766) (0.018 $\left.\mu \mathrm{g} \mathrm{L}^{-1}\right)$.

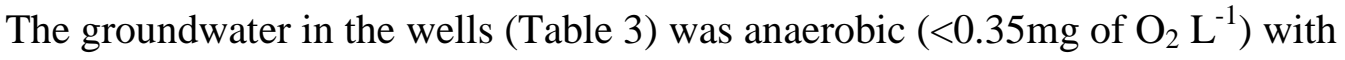
0.02-2.2mg L $\mathrm{L}^{-1}$ nitrate. Significant concentrations of dissolved iron, dissolved manganese, ammonium and methane indicate strongly reduced redox conditions. Dissolved iron was present in high concentrations $\left(52-68 \mathrm{mg} \mathrm{L}^{-1}\right)$ in the upper part of the aquifer, which could be explained by the reduction of iron (III) to iron (II). Low concentrations of sulphate $\left(0.5-5 \mathrm{mg} \mathrm{L}^{-1}\right)$ in the same area could be a result of sulphate reduction processes. $\mathrm{pH}$ values in the groundwater samples were neutral (pH 6.6- 8.3), while dissolved organic carbon (DOC) concentrations in the upper part of the aquifer (Well DGU-nr. 200.6164) were in the range of 29.3-33.7mg $\mathrm{L}^{-1}$. In summary, groundwater at the Nybølle site was characterized by anaerobic groundwater contaminated with two phenoxy acids - bentazone and BAM - in some of the 
monitoring wells in the area. None of the pesticides was detected in the two drinking water wells (well III and IV).

\begin{tabular}{|c|c|c|c|c|c|c|c|c|c|}
\hline \multirow[t]{2}{*}{ Parameter } & & \multirow{2}{*}{$\frac{200.3640}{\text { Well I }}$} & \multirow{2}{*}{$\frac{200.3862}{\text { Well II }}$} & \multirow{2}{*}{$\frac{200.3299}{\text { Well III }}$} & \multirow{2}{*}{$\frac{200.3169}{\text { Well IV }}$} & \multirow{2}{*}{$\frac{200.3766}{\text { Well V }}$} & \multicolumn{3}{|c|}{200.6164} \\
\hline & & & & & & & $\overline{\text { B1 }}$ & B2 & B3 \\
\hline \multicolumn{10}{|l|}{ Groundwater } \\
\hline Screen depth (mbs) & & $28-30$ & $9-24$ & 14-35 & 14-35 & $16.5-28.5$ & $6.5-7.4$ & $4.2-5.1$ & $2.7-3.6$ \\
\hline Temperature & ${ }^{\circ} \mathrm{C}$ & 4.0 & 9.0 & 9.1 & 9.0 & 9.1 & 8.3 & 7.7 & 6.8 \\
\hline $\mathrm{pH}$ & - & 7.4 & 6.9 & 7.2 & 7.1 & 7.1 & 8.3 & 6.7 & 6.6 \\
\hline Electrical conductivity & $\mu \mathrm{S} / \mathrm{cm}$ & 420 & 1055 & 540 & 489 & 599 & 1757 & 1984 & 1510 \\
\hline Oxygen & $\mathrm{mg} \mathrm{L}^{-1}$ & 0.35 & 0.1 & 0.1 & 0.2 & 0.03 & 0.1 & 0.02 & 0.1 \\
\hline $\mathrm{Cl}^{-}$ & $\mathrm{mg} \mathrm{L}^{-1}$ & 34.1 & 58.6 & 44.0 & 35.1 & 34.3 & 71.6 & 44.5 & 19.5 \\
\hline $\mathrm{Mg}^{2+}$ & $\mathrm{mg} \mathrm{L}^{-1}$ & 25.3 & 27.3 & 22.7 & 22.0 & 22.1 & 35.3 & 26.5 & 12.2 \\
\hline $\mathrm{Ca}^{2+}$ & $\mathrm{mg} \mathrm{L}^{-1}$ & 120.3 & 189.7 & 137.0 & 142.8 & 160.8 & 167.3 & 177.6 & 173.2 \\
\hline Mn (diss) & $\mathrm{mg} \mathrm{L}^{-1}$ & 0.03 & 0.1 & 0.04 & 0.03 & 0.1 & 0.1 & 0.5 & 0.6 \\
\hline $\mathrm{K}^{+}$ & $\mathrm{mg} \mathrm{L}^{-1}$ & 3.2 & 22.6 & 3.7 & 3.0 & 3.9 & 89.1 & 125.2 & 53.3 \\
\hline $\mathrm{CH}_{4}$ & $\mathrm{mg} \mathrm{L}^{-1}$ & 0.3 & 1.9 & 0.02 & 0.01 & 0.01 & 11.3 & 21.8 & 28.7 \\
\hline $\mathrm{SO}_{4}^{2-}-\mathrm{S}$ & $\mathrm{mg} \mathrm{L}^{-1}$ & 178.0 & 47.2 & 141.0 & 183.0 & 181.0 & 7.3 & $\begin{array}{r}2.0 \\
4.7\end{array}$ & 0.5 \\
\hline $\mathrm{Fe}$ (diss) & $\mathrm{mg} \mathrm{L}^{-1}$ & 2.0 & 1.5 & 0.7 & 0.5 & 2.5 & 6.7 & 52.0 & 68.6 \\
\hline $\mathrm{NO}_{3}^{-}-\mathrm{N}$ & $\mathrm{mg} \mathrm{L}^{-1}$ & 0.08 & 0.04 & 2.2 & 0.44 & 0.02 & $<0.1$ & $<0.1$ & $<0.1$ \\
\hline $\mathrm{NH}_{4}^{-1}$ & $\mathrm{mg} \mathrm{L}^{-1}$ & 0.6 & 0.6 & 0.4 & 0.2 & 0.3 & 4.7 & 5.9 & 4.3 \\
\hline Dissolved Organic Carbon & $\mathrm{mg} \mathrm{L}^{-1}$ & 1.8 & 8.0 & 1.8 & 1.7 & 1.8 & 29.5 & 33.7 & 29.3 \\
\hline ATP & $\mathrm{pg} / \mathrm{mL}$ & 58.0 & 11.1 & 23.4 & 2.8 & 6.7 & 30.5 & 17.1 & 18.7 \\
\hline
\end{tabular}

\subsection{Pesticide mineralisation potential in groundwater only experiments}

Screening results for the degradation potential of bentazone, mecoprop and dichlorprop in groundwater samples from the Nybølle site, with autoclaved chalk under oxygen-saturated conditions corresponding to $11 \mathrm{mg} \mathrm{L}^{-1} \mathrm{O}_{2}$, are shown in Figure 2. The degradation of mecoprop was limited, with only $2-5 \%$ of ${ }^{14} \mathrm{C}$-mecoprop recovered as ${ }^{14} \mathrm{CO}_{2}$ at the end of the experiment (Figure 2B). However, mecoprop was removed substantially during the experiment ( $>50 \%$ in 180 days). The observed degradation potential of mecoprop is in accordance with previous investigations involving chalk under aerobic conditions (Janniche et al., 2011, Johnson et al., 2000), although these lag phases were slightly shorter. In a study of the importance of initial concentration on biodegradation kinetics, mecoprop degradation was faster at a concentration of $100 \mu \mathrm{g}$ $\mathrm{L}^{-1}$ than at $1 \mu \mathrm{g} \mathrm{L}^{-1}$ (Toräng et al., 2003). No dichlorprop degradation was observed under aerobic conditions with any of the groundwater samples from the monitoring or drinking water abstraction wells (Figure 2C). This persistence of dichlorprop is in 
accordance with the findings of Pedersen (2000) at an initial concentration of $50 \mu \mathrm{g} \mathrm{L}^{-1}$ under aerobic conditions, but it contrasts with the complete degradation of dichlorprop in a laboratory column experiment (Tuxen et al. 2000) and a continuous field injection experiment (Broholm et al. 2001) in an aerobic aquifer.

Surprisingly, 30-44\% of bentazone was removed from the water phase over183 days, while only $5 \%$ was removed in the abiotic controls (Figure 2A). Bentazone mineralisation was lower than $1 \%$ in all the groundwater samples from Well I and Well II, but this was higher than in the autoclaved control incubations $(0.25 \%)$, thus indicating microbial mineralisation. Even though bentazone is usually considered to be recalcitrant in aquifers (Broholm et al., 2001), it was significantly removed at low concentrations in laboratory experiments with groundwater only. Thus, groundwater provides degradation potential.

The selected herbicides were not degraded or decreased in concentration in any of the abiotic control incubations with aerobic or anaerobic conditions. This indicates a microbially mediated process as opposed to removal by sorption only. Overall, our results suggest that groundwater from Well I and Well II displayed degradation potential for bentazone and mecoprop at the Nybølle site. 

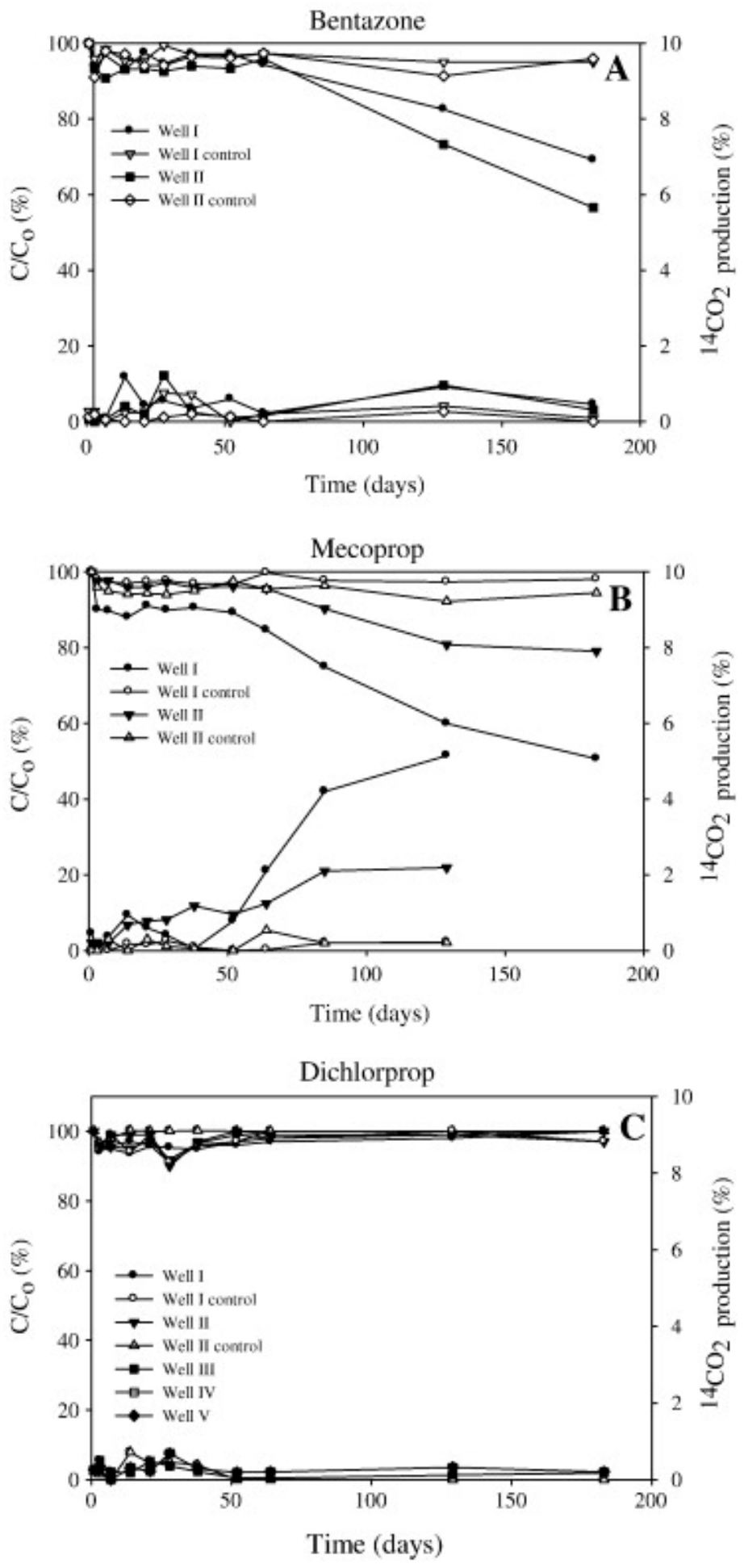

Fig. 2. Bentazone, mecoprop and dichlorprop concentrations (\% C/Co) and mineralisation (\% 14CO2) in groundwater from Wells I, II, III, IV or V (see Fig. 1 and Table 2) within autoclaved chalk under aerobic conditions at an initial concentration of $1 \mu \mathrm{g} L^{-}-1$. Controls are autoclaved and represented by open symbols. 
3.3 Mineralisation potential in groundwater and sediment experiments, stimulated by oxygen

The degradation potential for pesticides observed in groundwater from Well II (see section 3.2) was seen in supplemented aquifer sediment, which is considered to carry much more bacteria (Albrechtsen et al., 1996) and thus a higher degradation potential compared to incubations where microorganisms only are added by the water samples (Figure 2). The presence of fresh aquifer sediment resulted, in general, in a higher degradation potential at the highest addition of oxygen (equivalent to saturation) (Figure 3B, D, F). This was expressed as both degradation of all three herbicides and as a higher mineralisation degree. The importance of oxygen concentration for this degradation potential was investigated for bentazone, mecoprop and dichlorprop (Figure 3). All three pesticides were mineralised at both low $\left(0.1-0.4 \mathrm{mg} \mathrm{g}^{-1} \mathrm{dw}\right.$ corresponding to 0.5-2mg L $\left.{ }^{-1}\right)$ and high (0.76-1.67mg g ${ }^{-1} \mathrm{dw}$ corresponding to 4-11mg $\mathrm{L}^{-1}$ ) oxygen concentrations during the 200 days of incubation except for dichlorprop at an oxygen concentration below $0.37 \mathrm{mg} \mathrm{g}^{-1} \mathrm{dw}$ (corresponding to ca $2 \mathrm{mg} \mathrm{L}^{-1}$ ). No degradation was observed in the autoclaved control microcosms or in microcosms without added oxygen, thus verifying that the degradation was microbial. In most microcosms, the measured ${ }^{14} \mathrm{CO}_{2}$ production exceeded the radiochemical impurities level, therefore confirming the mineralisation of the added ${ }^{14} \mathrm{C}$-bentazone, mecoprop and dichlorprop.

The results also confirmed the requirement of oxygen for biodegrading the pesticides. Low oxygen additions resulted in almost linear mineralisation curves (Figure 3). At the higher oxygen additions $\left(0.76-1.67 \mathrm{mg} \mathrm{O}_{2} \mathrm{~g}^{-1} \mathrm{dw}\right)$ the mineralisation was 
faster, especially for bentazone and mecoprop (Figure 3B,D) in the first part of the incubation process.
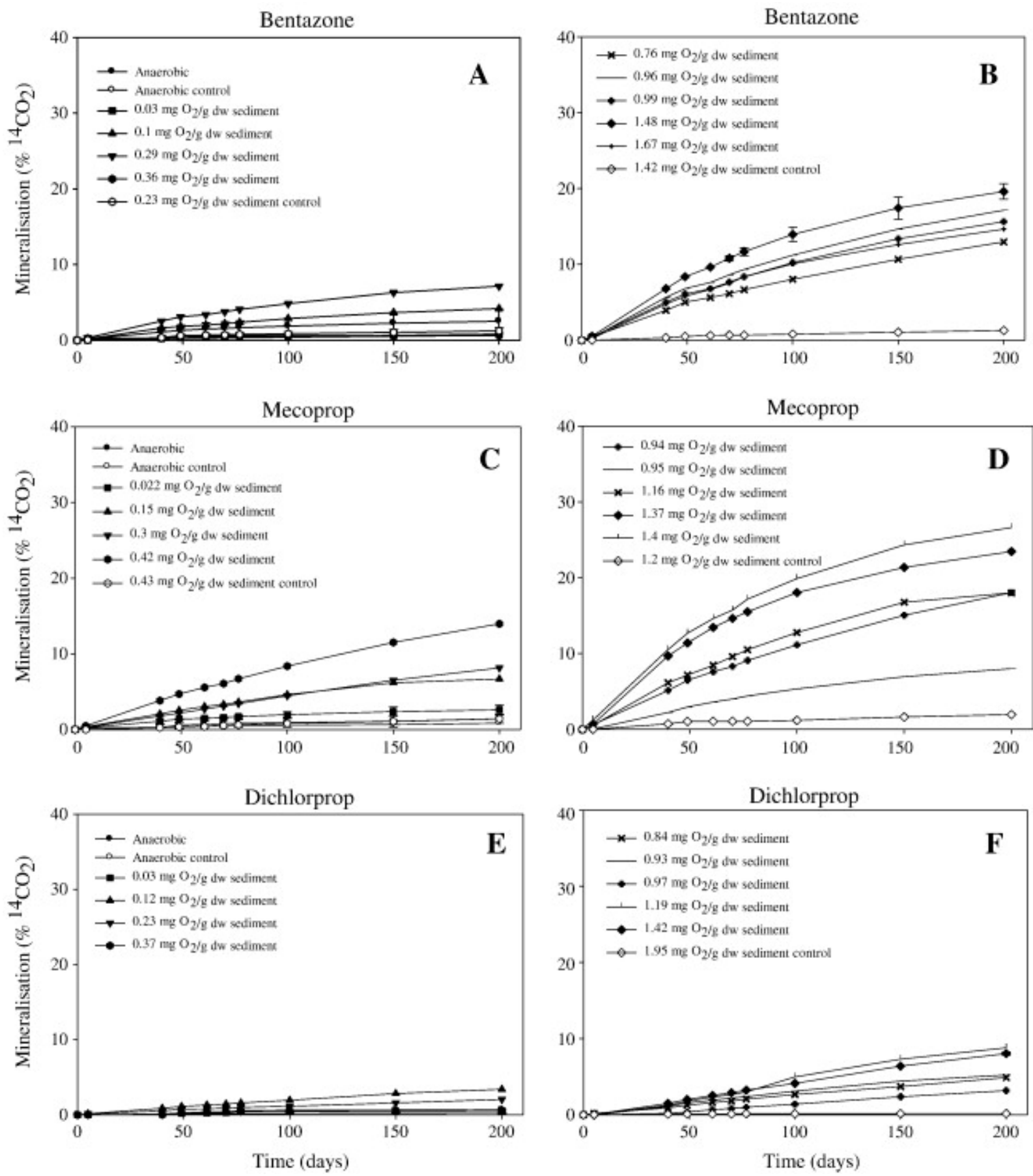

Figure 3: Mineralisation of 14C-labelled bentazone (A-B), mecoprop (C-D) and dichlorprop (E-F) to 14CO2 with groundwater from 200.3862 (Well II) and sand aquifer materials from 200.6164, amended with different oxygen concentrations. The mineralisation incubations were carried out as individual bottles (except in bottles amended with $0.0,0.1$ and $11 \mathrm{mg} \mathrm{L}-1$ oxygen, which were duplicates). Controls are autoclaved and represented by open symbols. 
Bentazone mineralisation was highest in response to $1.48 \mathrm{O}_{2} \mathrm{~g}^{-1} \mathrm{dw}$ sediment, corresponding to an oxygen concentration of $11 \mathrm{mg} \mathrm{L}^{-1}$, with $20 \%{ }^{14} \mathrm{C}$-bentazone mineralized to ${ }^{14} \mathrm{CO}_{2}$ (Figure 3A). Even at a low oxygen addition of $0.29 \mathrm{mg} \mathrm{O}_{2} \mathrm{~g}^{-1} \mathrm{dw}$ sediment, bentazone degradation was substantially increased compared to incubation without adding oxygen, reaching 7\% mineralisation in 200 days. Mecoprop degradation was highest in response to adding $1.4 \mathrm{mg} \mathrm{O}_{2} \mathrm{~g}^{-1} \mathrm{dw}$ where $27 \%{ }^{14} \mathrm{C}$-mecoprop was mineralized to ${ }^{14} \mathrm{CO}_{2}$. Degradation was lowest in samples with an additional $0.02 \mathrm{mg} \mathrm{O}_{2}$ $\mathrm{g}^{-1} \mathrm{dw}$ (Figure 3C). Degradation of mecoprop, with up to 53\% mineralisation at high oxygen concentrations and 32\% at low oxygen concentrations, was previously observed in laboratory experiments with point source-contaminated aquifer materials (Tuxen et al. 2006b). However, the pesticide concentrations investigated in that study were much higher (45 $\left.\mu \mathrm{g} \mathrm{L}^{-1}\right)$ than in our study.

Conclusively, biodegradation of the three herbicides was stimulated by adding oxygen, not only at high concentrations but also at substantially lower concentrations (0.4mg O $\mathrm{m}_{2} \mathrm{~g}^{-1} \mathrm{dw}$ (corresponding to $\left.2 \mathrm{mg} \mathrm{L}^{-1}\right)$ ). To date, bentazone mineralisation in aquifer sediment materials has to our knowledge not been documented. It is important and novel knowledge that bentazone at $1 \mu \mathrm{g} \mathrm{L} \mathrm{L}^{-1}$ can be mineralized in aquifer sediments with low oxygen amendment.

\subsection{Relation between oxygen addition and pesticide degradation}

Overall, the total mineralisation $\left({ }^{14} \mathrm{CO}_{2}\right.$ produced during 200 days of incubation) of the three investigated herbicides increased linearly according to the amount of oxygen added (Figure 4). For dichlorprop, the mineralisation was slower and subsequently the slope was smaller (Figure 4C). This linearity was somewhat surprising 
because thresholds were expected, e.g. a lower threshold below which no mineralisation was occurring, or an upper threshold above which the mineralisation was constant despite the increased addition of oxygen.
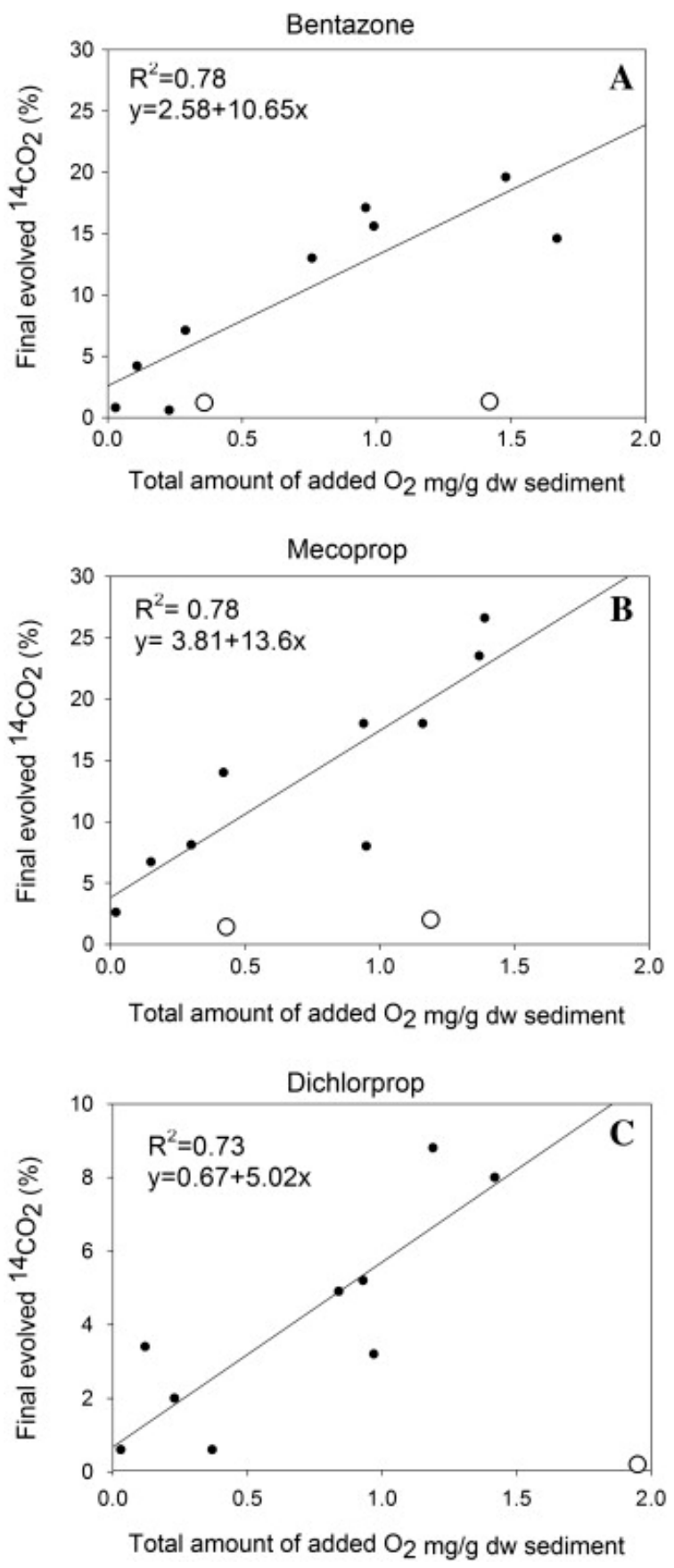

Figure 4: Effects of the total amount of oxygen added to each bottle during the experiments on final evolved 14CO2 (total amount of 14CO2 evolved) expressed as a \% of the amount of 14C-bentazone,mecoprop and dichlorprop initially added after the 200-day incubation period. The total amount of oxygen added to each bottle is calculated in relation to the sediment added to the bottles. 


\subsection{Oxygen consumption of sediment}

Oxygen was consumed very rapidly during the experiments, so it was a challenge to maintain a certain oxygen concentration in the microcosms. The total oxygen consumption in each microcosm was estimated as the accumulated amount of oxygen added during the incubation in order to maintain the desired oxygen concentration in the water phase. The differences between the total amount of oxygen added and the amount present in the bottles were set as the oxygen demand.

The relation between the total amount of oxygen added and oxygen concentration measured in the water phase (at day 100) is shown in Figure 5. By adding less than $0.3 \mathrm{mg} \mathrm{O}_{2} \mathrm{~g}^{-1} \mathrm{dw}$ sediment, oxygen consumption was fast, so additions below this amount did not leave any oxygen in the water phase. Furthermore, the substantial variation in oxygen consumption between the sediment in the different microcosms and the resulting oxygen concentration in the water phase shows the heterogeneities in the sediment.

The abiotic controls generally had a higher oxygen concentration than the biologically active sediments after adding a given amount of oxygen, which demonstrates that a major part of oxygen consumption is related to microbial activity. Oxygen is probably consumed in the sediment by oxidizing natural reductants such as organic matter, sulphides $\left(\mathrm{S}^{2-}\right)$, pyrite $\left(\mathrm{FeS}_{2}\right)$, ferrous iron $\left(\mathrm{Fe}^{2+}\right)$, siderite $\left(\mathrm{FeCO}_{3}\right)$ or manganese $\left(\mathrm{Mn}^{2+}\right)$ (Hartog et al. 2002). 


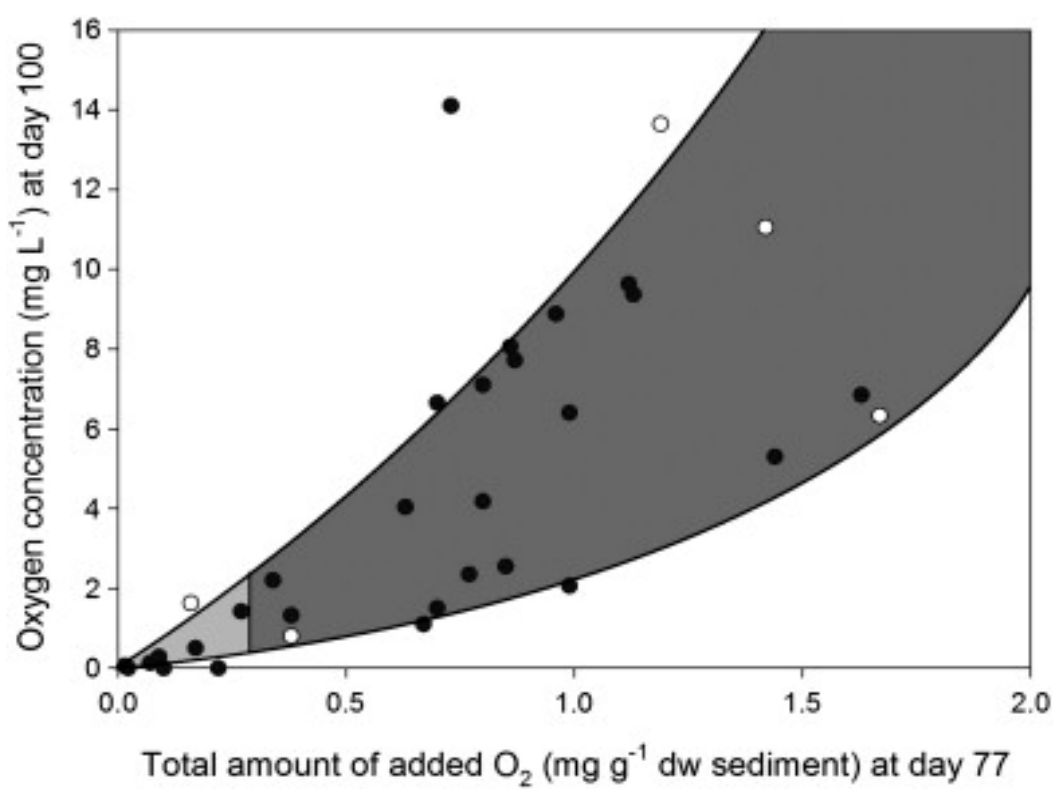

Figure 5: Relation between the total amount of oxygen added at day 77 and oxygen concentration measured in the water phase at day 100 . The light-grey area indicates rapid oxygen consumption, whereas the dark-grey area shows that oxygen concentrations reach ca. 2 $\mathrm{mg} \mathrm{L}-1 \mathrm{O} 2$ after adding a certain amount of oxygen. The open symbols indicate abiotic control incubations.

This oxygen consumption may limit the availability of oxygen needed for the degradation of contaminants (Heron and Christensen, 1995). Additions of more than $2 \mathrm{mg} \mathrm{O}_{2} \mathrm{~g}^{-1} \mathrm{dw}$ were needed to reach saturation in the water phase, and by the end of the experiment, after more than 200 days, the sediment was still consuming added oxygen, which indicates that the sediment had not fully oxidized. Tuxen et al. (2006a) reported oxygen consumption values between 2.2-2.6mg $\mathrm{O}_{2} \mathrm{~g}^{-1} \mathrm{dw}$ in laboratory studies with anaerobic sediments amended with oxygen comparable to our results.

An awareness of this substantial oxygen consumption is important in designing the field-scale bioremediation of pesticide-contaminated aquifers through adding oxygen, especially considering that the oxygen required directly to mineralize the added pesticides is almost insignificant. 


\section{Challenges in implementing oxygen-enhanced biodegradation}

The enhanced biodegradation of pesticides after adding oxygen - as observed in our laboratory experiments - is promising and may provide the potential for the microbial remediation of pesticide-contaminated abstraction fields. A significant challenge is the transfer of the results from the controlled degradation experiments in the laboratory to the field scale. Model simulations show that different pumping strategies (pumping rates, placement of pumping wells and screens) could result in different oxygen levels around the well or well field (Jepsen et al. 2012). It thus seems possible to form a pumping strategy whereby the resulting flow regime will mix shallow aerobic groundwater into the deeper anaerobic aquifer, consequently causing enhanced oxygen concentrations in the lower part of the aquifer. This will depend highly on local hydrogeological systems and infiltration patterns, including possible connections with aerobic stream waters. Thus, field testing of potential oxygen enhancement at the actual well fields would be needed to explore these model scenarios. Injecting oxygen into groundwater implies a high potential for physical and biological clogging. The oxygen may also oxidize reduced species in the sediment such as e.g. sulphides or ferrous iron which lead to dissolution of toxic compounds such as ar senic and nickel (Larsen and Postma,1997). Physical clogging might occur due to the precipitation of iron $\left(\mathrm{Fe}^{3+}\right.$ oxides) during groundwater aeration (Timmer et al., 1999) as a consequence of oxidation caused by iron bacteria. The microbial growth of iron bacteria on piped surfaces or on the walls of wells might lead to bioclogging of a porous medium with reductions in porosity and hydraulic conductivity (Seifert and Engesgaard, 2012). The development of preferential flow paths that consist of regions with high pore water 
velocity is also expected due to bioclogging. In addition, microorganisms might have less time to utilise the contaminant in regions with high velocity where hydraulic conductivity is reduced. Therefore, bioclogging may reduce the efficiency of contaminated groundwater bioremediation.

Nevertheless, our results for the degradation of pesticides are valuable in the development of treatment strategies for protecting drinking water wells. In situ solutions may be good alternatives to closing abstraction wells or employing advanced treatment processes at waterworks. In conclusion, the most suitable pumping strategy as a result of model simulations (Jepsen et al. 2012) could be the plausible strategy for implementing oxygen-enhanced biodegradation in aquifers simply by drawing oxygenated groundwater from the surface into the well. Thus, mixing aerobic groundwater from the upper part of the aquifer with the deeper anaerobic groundwater could result in increased oxygen concentrations and stimulated biodegradation of pesticides in the aquifer by pumping strategies.

\section{Conclusions}

The degradation potential of bentazone and mecoprop under aerobic conditions was evident in groundwater samples with autoclaved chalk material. The addition of oxygen stimulated the degradation of bentazone, mecoprop and dichlorprop at environmentally relevant concentrations $\left(1 \mu \mathrm{g} \mathrm{L}{ }^{-1}\right)$ for anaerobic aquifer sediment material. The relationship between total ${ }^{14} \mathrm{CO}_{2}$ production and the total amount of added oxygen was almost linear, and even adding small amounts of oxygen stimulated degradation. 
No degradation was observed in our anaerobic incubations, showing that oxygen was required in order to biodegrade the herbicides. Oxygen consumption by naturally occurring reduced species in the sediment was substantial, and significant amounts of introduced oxygen were needed to increase dissolved oxygen concentrations. Therefore, biodegradation stimulation could be limited by this high oxygen consumption. Proper mixing between oxygen containing upper groundwater and the water body with the contaminant could also be limited due to oxygen moving into high permeability zones while contaminants are present in low-permeability zones or clay layers. However, enhancing oxygen levels - even to relatively low concentrations - could be a promising bioremediation technology for drinking water abstraction fields, in order to microbially degrade herbicides arising from diffuse source contamination.

\section{Acknowledgements}

The study was funded partly by the European Union FP7 Integrated Project GOODWATER Initial Training Network under grant agreement no. 212683, which addresses the increasing global importance of biological groundwater remediation and the management of sites contaminated by organic chemicals. We also acknowledge the UrbanWaterTech Research School for its support, and we acknowledge Mona Refstrup, Jens S. Sørensen and Sinh Hy Nguyen for being active in the field and laboratory work. Finally, we thank Rasmus Jakobsen for his support in setting up the PHREEQC programme. 


\section{References}

Albrechtsen HJ, Smith PM, Nielsen P, Christensen TH. Significance of biomass support particles in laboratory studies on microbial degradation of organic chemicals in aquifers. Water Res 1996;30:2977-2984.

Barbash JE, Thelin GP, Kolpin DW, Gilliom RJ. Major herbicides in ground water: Results from the National Water-Quality Assessment. J Environ. Qual 2001;30:831- 845.

Broholm MM, Rügge K, Tuxen N, Højberg AL, Mosbæk H, Bjerg PL. 2001. Fate of herbicides in a shallow aerobic aquifer: A continuous field injection experiment (Vejen, Denmark). Water Resour Res 2001;37:3163-3176.

Buss SR, Thrasher J, Morgan P, Smith JWN. A review of mecoprop attenuation in the subsurface. Quart J Eng Geol Hydrogeol 2006;39:283-292.

Christensen TH, Bjerg PL, Banwart SA, Jakobsen R, Heron G. Albrechtsen HJ. Characterization of redox conditions in groundwater contaminated plumes. J Contam Hydrol 2000;45:165-241.

Damgaard I, Chambon J, Christiansen C, Broholm MM, Binning PJ, Bjerg PL. Erfaringsopsamling for reduktiv deklorering som afværgeteknologi i moræneler, Delrapport I;2009 (in Danish).

Jessen OZ. Opdatering af hydrologisk model for Nybølle. DHI, Final report, Februar 2001;2001 (in Danish).

Hartog N, Griffioen J, Van der Weijden $\mathrm{CH}$. Distribution and reactivity of $\mathrm{O}_{2}$-reducing components in sediments from a layered aquifer. Environ Sci Technol 2002;36:2338-2344. 
Heron G, and Christensen TH. Impact of sediment bound iron on redox buffering in a landfill leachate polluted aquifer (Vejen, Denmark). Environ Sci Technol 1995;29:187-192.

Huber R, and Otto, S. Environmental behavior of bentazon herbicide. Rev Environ Contam Toxicol 1994;137:111-133.

Janniche GS, Lindberg E, Mouvet C, Albrechtsen HJ. Mineralization of isoproturon, mecoprop and acetochlor in a deep unsaturated limestone and sandy aquifer. Chemosphere. 2010;81:823831.

Janniche GS, Mouvet C, Albrechtsen HJ. Vertical small scale variations of sorption and mineralization of three herbicides in subsurface limestone and sandy aquifer. J Contam Hydrol 2011;123:167-177.

Jepsen TS. Oxygen enhanced degradation of the herbicide bentazone in chalk aquifers. Master Thesis, Technical University of Denmark, Department of Environmental Engineering, DK-2800 Kgs. Lyngby, Denmark; 2012.

Johnson A, White C, Bhardwaj LC. Potential for isoproturon, atrazine and mecoprop to be degraded within a chalk aquifer system. J Contam Hydrol 2000;44:1-18.

Kanissery RG, and Sims GK. Biostimulation for the Enhanced Degradation of Herbicides in Soil. Appl Environ Soil Sci 2011;Vol. 2011. Kolpin DW, Kalkhoff SJ, Goolsby DA, SneckFahrer DA, Thurman EM. Occurrence of selected herbicides and herbicide degradation products in Iowa’s ground water. Ground Water 1995;35:679-688.

Kolpin DW, Thurman EM, Linhart SM. 2000. Finding minimal herbicide concentrations in groundwater? Try looking for their degradates. Sci Tot Environ 2000;248:115-122. 
Larsbo M, Stenstrom J, Etana A, Borjesson E, Jarvis NJ. 2009. Herbicide sorption, degradation, and leaching in three Swedish soils under long-term conventional and reduced tillage. Soil Till Res 2009;105:200-208.

Larsen, F, Postma, D. Nickel mobilization in a groundwater well field: Release by pyrite oxidation and desorption from manganese oxides. Environ Sci Technol 1997; 31: 2589-2595.

Leistra M, Smelt JH, Matser AM, Boyte JJ, van der Pas LJT. Rate of bentazone transformation in four layers of a humic sandy soil profile with fluctuating water table. Pest ManagSci 2001;57:1023-1032.

Li KB, Cheng JT, Wang XF, Zhou Y, Liu WP. Degradation of herbicides atrazine and bentazone applied alone and in combination in soils. Pedoshpere 2008;18:265-272.

Malaguerra F, Albrechtsen HJ, Thorling L, Binning PJ. Pesticides in water supply wells in Zealand, Denmark: A statistical analysis. Sci Tot Environ 2012;414: 433-444.

Milosevic N, Qiu S, Elsner M, Einsiendl F, Maier MP, Bensch HKV, Albrechtsen HJ, Bjerg P.L. Combined isotope and enantiomer analysis to assess the fate of phenoxy acids in a heterogeneous geologic setting at an old landfill. Wat Res 2013;47:637-649.

Parkhurst DL, and Appelo CAJ. User's guide to PHREEQC (Version 2) - A computer program for speciation, batch-reaction, one-dimensional transport, and inverse geochemical calculations, U.S. Geol. Surv. Water-Resources Investigations Report. 1999;99-4259, 312pp.

Pedersen PG. Pesticide degradability in groundwater: Importance of redox conditions. PhD thesis.Technical University of Denmark, Department of Environmental Science and Engineering, DK-2800 Kgs. Lyngby, Denmark;2000. 
Rambøll, 2005. Technical report, Nybølle Indsatsområde. Hovedrapport. Kortlægning af grundvandsressourcens sårbarhed og anbefalinger til indsatstemaer, Københavns Amt (In Danish).

Region Hovedstaden, 2008. Rapport. Afgrænsende undersøgelse på Nybøllevej Losseplads, Egedal Kommune. Lokalitetsnummer 171-00001.

Reitzel LA, Tuxen N, Ledin A, Bjerg PL. Can degradation products be used as documentation for natural attenuation of phenoxy acids in groundwater? Environ Sci Technol 2004;38:457-467.

Rodriguez-Cruz S, Jones J, Bending G. Study of the spatial variation of the biodegradation rate of the herbicide bentazone with soil depth using contrasting incubation methods. Chemosphere 2008;73:1211-1215.

Seifert D, and Engesgaard P. Sand box experiments with bioclogging of porous media: Hydraulic conductivity reductions. J Contam Hydrol 2012;136:1-9.

Smith AE. Degradation, fate and persistence of phenoxyalkanoic acid herbicides in soil. Rev Weed Sci 1989;4:1-24.

Thorling L, Brüsch W, Hansen B, Langtofte Mielby SC, Møller RR. Grundvand. Status og udvikling 1989 - 2012. Teknisk rapport, GEUS 2012. Groundwater Monitoring 2012. GEUS, Denmark;2012 (in Danish).

Timmer H, Verdel JD, Stuyfzand PJ. Deep recharge clogging in Langerak, the Netherlands. Final Report, EU Project on Artificial Recharge of Groundwater;1999. http://project.vki.dk/artificial_recharge.

Tomlin CDS.The Pesticide Manual. British Crop Protection Concil, UK;1997. 
Toräng L, Nyholm N, Albrechtsen HJ. Shifts in biodegradation kinetics of the herbicides MCPP and 2,4-D at low concentrations in aerobic aquifer materials. Environ Sci Technol 2003;37:30953103.

Tuxen N, Tuchsen PL, Rugge K, Albrechtsen HJ, Bjerg PL. Fate of seven pesticides in an aerobic aquifer studied in column experiments. Chemosphere 2000;41:1485- 1494.

Tuxen N, Reitzel L, Albrechtsen HJ, Bjerg PL. Oxygen-enhanced biodegradation of phenoxy acids in ground water at contaminated sites. Groundwater 2006a;44:256-265.

Tuxen N, Albrechtsen HJ, Bjerg P.L. Identification of a reactive degradation zone at a landfill leachate plume fringe using high resolution sampling and incubation techniques. J Contam Hydrol 2006b;85:179- 194. 